\title{
Travel in Rībi Hideo's Novels or the Search for an Alternative Writing Style in Japanese
}

Dan Fujiwara

University of Toulouse - Jean Jaurès / French Research Institute on East Asia (IFRAE)

\section{Introduction}

Since the early I990s, $^{\mathrm{I}}$ the Japanese literary scene has seen the emergence of works which, although marginal in number, have come to be collectively categorized as "border-crossing literature" (ekkyō bungaku $)^{2}$ or "Japanese-language literature" (nihongo bungaku). ${ }^{3}$ Characterized primarily by being written in Japanese by non-native authors, these works have tended to be analyzed in the light of the globalized modern world, which anthropologist Aoki Tamotsu calls the "age of big movement of information, people and things" (bito mono jyōhō no dai-idō no jidai) (Aoki, 200I), and the challenges it faces, including multilingualism, multiculturalism and national identity crises. A number of studies have explored this literary genre within the context of today's globalized world (Sakamoto, 2006; Yoshihara, 2000).

I The present chapter was originally a paper presented at the I 2 th National and 3 rd International Conference of the Association for Japanese Studies in Spain (entitled Japan: Tourism as a path to knowledge and development) in Madrid on 5-7 October. The title of my presentation was: 'Travelling as language trouble in Levy Hideo's works.'

2 Japanese words are spelled using the Hepburn Romanization system.

3 For a general picture of this literary genre, see Numano (I998), Kaku (2013), Tsuchiya (2009).

How to cite this book chapter:

Fujiwara, D. 202I. Travel in Rìbi Hideo's Novels or the Search for an Alternative Writing Style in Japanese. In: Jonsson, H., Berg, L., Edfeldt, C. and Jansson, B. G. (eds.) Narratives Crossing Borders: The Dynamics of Cultural Interaction. Pp. 405-428. Stockholm: Stockholm University Press. DOI: https://doi.org/IO.I6993/bbj.r. License: CC-BY 4.0 
Ribi Hideo (born I950), ${ }^{4}$ whose writing style will be discussed in this chapter, is widely known as one of the most representative writers of "border-crossing literature" in Japanese, alongside authors David Zoppetti (born I962 in Swiss), Yang Yi (born I964 in China), Arthur Binard (born 1967 in the United States), Jeffrey Angles (born I97 I in the United States), Shirin Nezammafi (born 1979 in Iran), and Li Qinfeng (born I989 in Taiwan). Other famous members of this group are Tawada Yōko (born I960)5 and Mizumura Minae (born I95 I), ${ }^{6}$ both writing profoundly influenced by their experience abroad and foreign language knowledge. As is clear from the exteriority or the "exophonic" 7 character of these writers, one of the most important challenges of these writers is to reconsider the definition of Japanese literature, or to be more precise, its national border that even today some tend, as Komori Yōichi states, to assume as being evident when talking about Japanese literature or even simply Japanese language (Komori, I998: 5-9).

This recent-marginal but significant-attempt at crossing the national border of Japanese literature is not an unprecedented matter. So-called "Japanese literature of Korean residents in Japan" (Zainichi chōsenjin bungaku) and "Taiwanese literature in Japanese under the Japanese Rule" 9 are fine examples for this. Yet "border-crossing literature in Japanese" I will discuss here is somewhat different from these postcolonial literary genres in terms of the context within which writers choose Japanese language for writing. Most of today's border-crossing writers in Japanese use this language for personal—or even esthetic-reason, rather

4 The author's real name is Ian Hideo Levy but in the Japanese public space (publications, talks), he systematically calls himself “Rỉbi Hideo," using the Japanese writing system: リービ英雄.

5 She is living in Germany from the beginning of the I980s and writes both in Japanese, her mother tongue, and German, her adopted language.

${ }^{6}$ She grew up in the United States from the middle of the I960s to the I980s and her conception of literature is deeply inspired by modern Japanese literature, especially from the Meiji era (I868-I9I2).

7 In the words of Tawada (2003).

${ }^{8}$ For more details and a larger perspective about this genre, see Kawamura (1999).

9 For more details and a larger perspective about this genre, see Tarumi (1995) and Kleeman (2003). 
than for socio-political one originated in Japanese colonization in East Asia during World War II. Certainly, Rỉbi’s biography, in particular his childhood still reveals cold war tensions in Asia in the I950s and I960s. However, it is evident that for Ribi, the decision of switching from English, his mother tongue and one of the major languages in our world today, to Japanese, a minor Asian language, is largely based on his personal literary sensibility and conviction for the possibilities of his adopted language, as the author repeatedly emphasizes in his essays. ${ }^{10}$

Indeed, Ribi's entire biography is inextricably linked to the idea of "border-crossing" (ekkyō), a concept he employs to characterize his own literary oeuvre (Ribi, 2007). Born in I950 in the United States (Berkley) to a Jewish father and a Polish-American mother, Ribi spent his childhood in Taiwan, where his father started his career as a Sinologist diplomat, and Hong-Kong, after his parents' divorce in I960. Two years later, he came back to the United States (Washington D.C.) with her mother in order to provide medical care to his mentally disabled younger brother. Following his first trip to Japan in 1964, Ribi developed a deep fascination with its nature and culture, even obtaining in 1978 a doctorate in Japanese literature from Princeton University with his Ph.D. dissertation entitled Hitomaro and the Birth of Japanese Lyricism. ${ }^{\text {I }}$ Thus, shortly after receiving his Ph.D., he launched an academic career at Princeton and then at Stanford. In I98I, he published an English translation of the first five volumes of Japan's first imperial poetry anthology Man'yōshū (The Ten Thousand Leaves) and won the National Book Award for Translation in the next year. However, as a regular visitor to Japan with a strong urge to live there permanently, Rỉbi began writing in Japanese in earnest in the mid-I980s, enthusiastically supported by the novelist Nakagami Kenji (I946-I992). Ribi's debut Japanese-language novel, Seijōki no kikoenai heya (A Room Where the Star-Spangled Banner Cannot Be Heard) (Ribi, I992) ${ }^{\mathrm{I} 2}$, was published in the

ro See Ribi (2010).

II The dissertation was published by Princeton University Press in I984.

${ }^{12}$ This work, combined with two other short novels, was published in book format by Kōdansha and won the I 4 th Noma Literary New Face Prize (Noma Bungei Shinjin-shō). 
March I 987 issue of Gunzō, a leading Japanese literary magazine. In I990, he definitively abandoned his distinguished academic career to settle in Japan and continue writing, always in his adopted language of Japanese. He has published seven fictional and twelve no-fictional books so far. ${ }^{13}$

It is no doubt that this Ribi's pluralistic origin and life course deeply influence his oeuvre, in particular its narrative setting, which systematically involves traveling and movement. The main character is invariably an American translator based in Tōkyō (or occasionally a university lecturer), born to multiethnic and multicultural parents, who travels between Japan, the United States, China and Taiwan. However, a careful reading reveals that in contrast to this mobility, which can be easily linked to the context of today's globalized world order, the travels described in Ribi's works are not so free-flowing, but rather, deeply related to the issue of what I conveniently call "language trouble." As Nagaoka (2009) has already discussed, Rỉbi's novels are above all concerned with language. Indeed, his traveling protagonists are constantly anxious and distrustful of everything around them, in particular the languages-English, Chinese, Southern Min, or Korean-they hear and use. As Kleeman (20I3) argued, "multi-lingual simultaneity" is one of the most striking features of Rỉbi's works. The protagonists think in Japanese, going back and forth between this and the other languages, tortured by their realization that language is opaque. This realization of "language trouble" constitutes the main event of each trip and story. For Ribi's protagonists, the languages encountered in the context of traveling have no clear and transparent relation to one another; they do not circulate between each other but rather exclude one another.

For Rỉbi, traveling or "crossing borders" is above all a linguistic experience in the sense that it provokes critical thinking on the potential and limits of languages. Ribi's oeuvre, which highlights the asymmetric, instable and opaque relationship between languages, stands in contrast to the main aspects of the modern

${ }^{13}$ For further details on the author's biography from I950 to 20 I I, see Ribi (2OII). 
globalized and border-crossing world and could therefore be seen as a counter-model. Accordingly, this chapter seeks to analyze Ribi's novels by focusing on the "language trouble" brought about by the travel situations described. This analysis will then be developed to show how this "language trouble" can be linked to the author's search for his own style of writing in Japanese.

\section{Travel in Rỉbi Hideo's Novels}

Reading Rìbi's novels we can distinguish four distinct travel destinations.

First of all, there is a trip from the United States to Japan, and more specifically, from the United States Consulate in Yokohama to Shinjunku in Tōkyō. This trip is described in the author's first novels (Ribi, I992)-Seijōki no kikoenai heya, Nobenbā (The End of November), and Nakama (One of the Guys), all set in the late I960s and featuring the main character named Ben Isaac, a seventeen-year-old American.

Secondly, there is a journey from Japan to China (or, as Rỉbi often writes in his texts, "the mainland," tairiku), the most frequent destination for Rībi's protagonists. In Ten'anmon (Tiananmen) (Ribi, I996), ${ }^{14}$ the author's first novel dealing with this country, the destination is Tiananmen Square in Beijing. However, Ribi's protagonists also travel to more peripheral areas, far from the big cities. In Manshū ekusupuresu (Manchurian Express) (Ribi, I998), the protagonist visits Manchuria (Northeast China) to find the childhood home of world-renowned Japanese novelist Abe Kōbō (1924-I993). Ka to hae no dansu (The Dance of Mosquito and Fly) (Rībi, 2002), Henrī Takeshi Rewitsukī no natsu no kikō (Henry Takeshi Levitzky's Summer Journey) (Rỉbi, 2002), and Gaze (I Am) (Ribi, 2008a) are largely based on the author's travels to Kaifeng, known for being one of the oldest cities in China and its former capital during the Song dynasty. Here, the protagonist learns that a Jewish community (to which he belongs through his Jewish father) existed one thousand years ago. In Kōsokukōro nite (On a National Highway), Rōkokudō (An Old National Road)

${ }^{14}$ This novel was nominated for the II5th Akutagawa Prize (Akutagawa-shō). 
and Kari no mizu (Fake Water) (Rỉbi, 2008a), Rỉbi focuses on the city of Yan'an as the protagonists attempt to understand contemporary China, far from Beijing and Shanghai. ${ }^{15}$

The third place featured in Ribi's novels is the United States, which the protagonists travel to from Japan. The exact destination is always Washington, the city to which the protagonists are connected by family relationships. Kokumin no uta (Ode to the Nation) (Ribi, I 998), which describes the protagonist's journey to see his mother and mentally disabled brother, is one of the most important examples. Conversely, the narratives in Chiji ni kudakete (Thousands and Thousands of Pieces) and Konechikatto abenyu (Connecticut Avenue) (Ribi, 2005) ${ }^{16}$ are set in a more global context, specifically in the peculiar circumstances of 9.I I, which Rỉbi experienced from a distance as he arrived at Vancouver airport on that day to catch a connecting flight to New York.

Lastly, there is a journey from Japan to Taiwan (a deeply personal destination for Ribi), as seen in the author's most recent work, Mohankyō (Model Village) (Rỉbi, 20I6a) ${ }^{17}$. This country generally appears in reminiscences by the main characters on their childhood, although the exact destinations travelled to and the characters' names may differ. In this respect, it is significant that Mohankyō deals with the narrator-protagonist's journey to Taiwan to find this childhood home. Taiwan connects all of Ribi's novels and creates a strong narrative core throughout the author's entire oeuvre. ${ }^{\mathrm{I} 8}$

These four destinations share certain common aspects. One of them is that the protagonists' movements (on foot or by taxi, bus, train, airplane, or other transportation mode) constitute the main event of each novel. So remarkable is this feature that it is no exaggeration to describe the narration of Ribi's novels as consisting in an endless variation on the basic sentence "I walk," one of the most frequently used verbs of movement in Ribi's texts.

${ }^{15}$ The book won the 2oth Itō Sei Literary Prize (Itō Sei Bungaku-shō). Rībi has written a non-fictional work about this journey. See Ribi (2008b).

I6 The book won the 32 th Osaragi Jirō Prize (Osaragi Jirō shō).

${ }_{17}$ The book won the 68th Yomiuri Prize for Literature (Yomiuri Bungaku-shō).

I8 See Sasanuma (20II). 
However, the most striking feature is a close relationship between these four destinations the protagonists travel to-or recall-and the author's personal history. As I previously summarized, these destinations are places quite regularly visited or even lived by the author in his real life. ${ }^{19}$ This is significant, since it underlines the fact that Ribi's oeuvre is deeply rooted in his personal history, although suggesting some aspects of the modern globalized world to readers. Moreover, this autobiographical character is also clearly visible in the obvious similarities between the main characters and the author (age, origin, family relationships, setting in Tōkyō, Japanese as adopted language, profession, etc.). Nevertheless, it is worth emphasizing that these works, which can be read as being based on the author's real personal experiences, are not written as mere ethnographical travel reports. As Rỉbi mentions himself, he defines that his oeuvre is neither non-fiction nor pure fiction, but rather, has both of these two aspects at the same time, namely, being "structured by double narration" (katari no nijūkozō) in his words. ${ }^{20}$ Indeed, this "double narration," or the ambiguity of narrative genres is the dominant trope of Ribi's oeuvre. Mohankyō just mentioned above has reinforced this by its meta-narrative discourse, since "I" narrator-protagonist, named precisely "Ribi Hideo," does designate himself the author's other novels written as third-person narratives, narratologicaly distancing the protagonists featured in these narratives from Ribi himself. Thus Ribi's writing is developed in the interstices between his personal history and critical awareness of this.

Although each of these aspects merits fuller exploration, of most particular interest here is the main characters' obsession with the languages used by those around them as they travel. What makes this feature even more fascinating is the way the protagonists, many of them professional translators, try in vain to translate back and forth between Japanese, English and Chinese in their thoughts and speech, only to inevitably become aware of the asymmetry between languages, the opacity of languages. It is this that I term "language trouble" and which I posit is one of

\footnotetext{
I9 See Ribi (20II).

20 See Rỉbi (2016b, p. 223).
} 
the most persistent thematic preoccupations of Ribi's novels. It should be noted that Ribi describes these "language troubles" in Japanese, essentially a foreign language for him. He could actually have chosen English, his mother tongue to show objectively and share widely this issue. Yet, whereas he sets all of his protagonists as native English speakers like himself, it is basically in Japanese that the narrators of his novels tell stories and express the protagonists' thoughts, feelings and speech. Certainly, this exophonic process of writing one's own personal history in other's language can be adopted for various reasons. Nevertheless, in the case of Ribi, the aim of writing seems not merely to reproduce faithfully his personal border-crossing experience. But rather, as I will demonstrate in the following section, it can be assumed that for Ribi the reason for the choice of Japanese language is linked to the search for the possibilities of re-presenting his personal history as literary creation in its strong meaning. That is why he needs to set his narratives in traveling situations where "language trouble" is highly involved and thereby literary creativity is strongly emerging.

The following section seeks to illustrate this point by analyzing specific examples and showing how the author creates his own writing style by featuring this "language trouble."

\section{Language Trouble: Fragmentation, Untranslatability, and Challenging the Limits of Readability}

The first example is taken from Rỉbi's debut novel, Seijōki no kikoenai heya, published in the literary magazine Gunzō in 1987. This passage was chosen because it features the fundamental elements associated with "language trouble," namely, a situation that involves movement, a desire on behalf of the main character to read and understand other languages, and his ensuing feelings of unease and suspicion. And it should be noted that from his very first work in Japanese the author has already had a strong grasp and expression of the issue of ambiguous border between languages within the context of movement.

The traveling situation within which the story, set in the late I 960 , takes place is quite unusual because it actually follows Ben Isaac, a seventeen-year-old American, who runs away from the 
United States Consulate in Yokohama, where his father serves as consul, to Shinjuku, where wide scale student protests are underway. ${ }^{21}$ In discovering the urban night life of Tōkyō with a Japanese student named Andō, who refuses to speak English with him, and developing a strong fascination with the Japanese language, the young protagonist becomes aware of various elements within his inner world-his origin and childhood in Taiwan-that ultimately provoke a feeling of unease about his identity, a situation that will be familiar to readers of Ribi's works. The following passage describes the teenage protagonist who has just boarded a train to Shinjuku for the first time:

Ben's eyes drank in their first full view of a Japanese city at night. Unlike during the day, the outlines of the buildings blurred, and everywhere he looked neon signs squirmed quietly in kana and kanji. They reflected the dreams and ailments of the city in colors to match: WHISKY, PHARMACEUTICALS, TURKISH BATH, and CLINIC. From station to station, they transmitted the city's secrets, which were not meant for the eyes of a young boy from somewhere else.

Indeed, Ben couldn't read most of the characters. And even if he could, he could not fully understand what they meant. For Ben was still a traveler who could barely read road signs. In Yokohama the train started gradually to fill with passengers. Some looked on him with pity, others with ridicule, others with shock, discovering in Ben's intense blue-gray eyes a burning desire to know the world around him. (Rỉbi, I992, pp. 9-IO. Trans. Christopher D. Scott, 2OI I, pp. 3-4) $)^{22}$

In this example that we can find in the beginning of the novel, the teenage protagonist, who has just escaped from his father's place (the consulate), is looking at neon signs from the train window. Today, this Japanese urban nightscape has become quite commonplace; images of it have circulated around the world and have

${ }^{21}$ In the late I960s, a number of student protest movements arose in Japan, mirroring other countries like the United States and France. Contentious issues included the construction of Narita International Airport, the Vietnam War, and the renewal of the Treaty of Mutual Cooperation and Security between the United States and Japan (Nichibei Anzen Hoshō Jyōyaku), also known in Japanese as Anpo.

${ }_{22}$ See Appendices for the original Japanese text. 
become "globalized." However, this passage does not solely reproduce the stereotypical image. Instead it also depicts Ben's feelings, musings, and physical reactions to the illegible Japanese characters impressed on each neon sign, as highlighted by the translator's use of capital letters. ${ }^{23}$ In other words, it illustrates the protagonist's struggle caused by the conflict between his awareness of his inability to read and his "burning desire" to understand the "city's secrets" concealed within these characters.

Moreover, what should be noted is that this conflict also influences the text. This is evident in the phrase "in Ben's intense blue-gray eyes a burning desire," which uses strikingly symbolical language to emphasize contrasts in color and temperature (blue/ burning). The protagonist's feeling of being alienated- "a young boy from somewhere else" - can be seen as another symptom of this inner conflict. Furthermore, the inner conflict is also visible in the narrative structure, within which the inside of the young protagonist is depicted precisely in Japanese, the language of "others" that he cannot read or understand, whereas in this context English could have been a suitable and logical choice for him since it is his mother tongue. This contradictory narrative structure might suggest that the narrator's description in Japanese results from a "burning desire" or even fantasy of the protagonist who is eager to live precisely in this language of "others."

Although the quoted section seems to describe a fairly short moment within the story, most of Ribi's novels show the main characters as constantly obsessed with whether or not they can read, whether or not they can understand other people's languages. The fact that many of the protagonists are translators is surely not irrelevant to this obsession.

However, Ribi's work does not focus solely on describing the main characters' troubled state of mind. As illustrated in the following quote from Ten'anmon, published in the January 1996 issue of Gunzō, the "language trouble" experienced by Ribi's protagonists is also visible in the narrator's descriptions themselves with a particular focus on another feature of "language trouble,"

${ }^{23}$ In the original Japanese text, the author puts these words in brackets in order to emphasize them. 
namely, the idea of "fragmentation" (dampen in the original Japanese text).

Ten'anmon is Ribi's first novel to deal with China and sees the protagonist visiting Beijing's Tiananmen Square just a few years after the protests of 1989 to view the body of Mao Zedong. The following passage describes the protagonist ordering a glass of bourbon from a Chinese stewardess in the airplane bound for Beijing:

He tried to ask her in mainland Chinese if she was from the mainland but lost his nerve before he could even say "Nǐ shì (Are you) ...?" Then, like a black willow leaf suddenly shaken by the breeze, she moved down the aisle and disappeared from view.

It was the first time in thirty years such words had tried to leave his lips.

Nǐ shì yú dàlù chūshēng de ma ? Nǐ shì zài dàlù zhăngdà de ma?

Were you born on the mainland? Did you grow up on the mainland? Fragments of this language he had so often heard thirty years ago, in the mouths of exiled mainland generals in a provincial city on the defeated army's island, came to mind.

He tried to turn the sentence around by mentally spelling out "Wó shì... (I am...)" in mainland Chinese.

"Wò shì Ribèn... (I'm Japanese...)"

He tried to remember how to say person (rén) in Chinese.

He started again: "Wŏ shì Ribèn de... (I'm a kind of Japanese...)" Is that really how you say it, he wondered. The fragments of recently recalled words hung in his mind, then disappeared. (Ribi, I996, pp. I4-I5. My own translation. The sentences in italics appear in Chinese in the original text. $)^{24}$

In this passage, we can find the protagonist going back and forth in his mind between Japanese and "mainland Chinese" " tairiku no kotoba"), a familiar situation to Ribi’s works. However, it should be noted that the protagonist's thoughts on the act of translating is not so free flowing as the narrator depicts it with the idea of "fragmentation" (dampen in the original Japanese text). Instead, the focus is clearly put on the protagonist's hesitation in

${ }^{24}$ See Appendices for the original Japanese text. I particularly thank my colleague, Vanessa Teilhet, for her precious help in providing the pinyin transcriptions. 
engaging in a conversation with the stewardess. Furthermore, it is interesting to see that the idea of "fragmentation" also influences the way the narrator constructs the description of this scene, with the sentences seeming to overlap one another. In the "language trouble" caused by the encounter with another language, the protagonist's thoughts, as well as the language expressing them, cease to move fluently, "h[a]ng in his mind (chüburarin to natte)" like "fragments," and cause the protagonist to fall silent.

Generally speaking, Rỉbi's narratives do not develop in such a way as to see the "language trouble" resolved and replaced by a clear and transparent knowledge of other people's languages. Instead, the protagonists remain deeply puzzled about the otherness of the languages they are trying to read and understand. Just like the main character in Ten'anmon, they ultimately decide not to say anything in front of their interlocutors and become silent, stuck in feelings of unease and suspicion caused by "language trouble".

Chiji ni kudakete, published in the September 2004 issue of Gunzō, provides another more complete example of how "fragmentation" influences the author's writing style. Indeed, this novel describes an unfinished journey in which the protagonist, a fifty-something man and long-standing resident of Tōkyō named Edward, is travelling to the United States to visit his mother and stepsister in Washington. By sheer coincidence, it is the day of the terrorist attack on New York and he is detained in Vancouver trying to catch his connecting flight to New York. After spending a week there, he is obliged to return to Tōkyō. The narrative thus focuses on the protagonist's interrupted journey between Tōkyō and New York. The following passage describes the protagonist having just landed at Vancouver airport:

The Air Canada plane slowed down as it moved along the runway. Then suddenly, and yet completely naturally, it came to a halt, as if it had run out of breath and simply given up.

The ground and trees gently passing outside the window ceased moving and stood still under the white sky.

Edward heard people speaking quietly in English or Japanese, a little Chinese too. Above the buzz of conversation, the voice of a man in his fifties rang out over the loudspeaker. 


\section{Sometimes}

It was the captain's voice. It sounded like an American speaking but the accent was softer than usual.

Edward had never heard this word sometimes in a captain's announcement.

Involuntarily, he murmured in Japanese: sometimes.

Sometimes a captain...

Sometimes a captain...

The captain's voice seemed to be hesitating, breaking a little. And then it continued slowly saying must.

... give bad news

That's what the captain was saying.

We've had some news

The voice from the loudspeaker stopped, again, briefly. The pilots might have heard the news several hours ago. In a flat voice the captain began again,

The United States

Then slowly, in a gentle tone, he continued,

has been a victim

The words made no sense to Edward. A strange translation formed in Japanese in his mind.

The United States has been a victim

\section{of a major terrorist attack}

The United States has been the victim of a major terrorist attack

I can't give any details yet

The voices speaking in English gradually subsided. A few Japanese and a group of Chinese continued talking, unaware. Others passengers in front and behind gave exclamations of surprise in an unrecognizable language. (Rỉbi, 2005, pp. I4-I7. My own translation. The sentences in italics appear in English in the original text. $)^{25}$

As with Ten'anmon, what strikes at first glance is the hybridity of the author's writing style; in other words, the mixing of Chinese

${ }_{25}$ See Appendices for the original Japanese text. 
(in the case of Ten'anmon) and English words and sentences in the protagonists' minds directly with the Japanese, illustrating the protagonists going back and forth between languages while struggling with feelings of unease and suspicion. It can be said that the hybridity of this passage visually reflects the primary feature of Ribi's oeuvre focusing on movements from one language to another.

However, at the same time, it is also necessary to pay attention to other effects resulting from this textual hybridity. Indeed, in the present example, the fragmented writing used to depict this "language trouble," also highlighted in the quote taken from Ten'anmon, does not take place merely in the protagonist's musings or the expressions the narrator employs. Ribi also physically breaks the text's linguistic unity and consistent phrasing. In short, Ribi's hybrid writing leads to fragmentation and disturbance of Japanese language that he adopted to recount the experience of 9.II. Each sentence is divided into several short phrases using numerous punctuation marks and frequent new lines or several blank lines in unusual manner comparing to standard written Japanese. This fragmentation in the "language trouble" characterizing Ribi’s novels illustrates the protagonists' sense of incongruity and unease over the asymmetry between languages, a critical situation that could be called "untranslatability" as Numano (2008, p. 272) emphasizes in his commentary on Chiji ni kudakete.

The passage from Chiji ni kudakete, quoted as one of the examples of "fragmentation" in Ribi's texts, should be linked not only to its general context that it describes, that is, an unexpected halt at Vancouver airport, but also to the fact that the primary theme of the novel in which this passage is included is the protagonist's unsuccessful journey from Tōkyō to New York. Moreover, in taking into account the novel's title, Chiji ni kudakete, which literarily means "broken in thousands of pieces," ${ }^{26}$ we can emphasize how deeply this passage pictures overall conception of this novel in a condensed manner and at different textual levels precisely owing to its fragmented writing style.

${ }_{26}$ This sentence is actually taken from Matsuo Bashō (I 644-I694)'s haiku: "All those islands! / Broken into thousands of pieces, / The summer sea." (Shimajima ya / Chijini kudakete / Natsu no umi.) (trans. Makoto Ueda. Matsuo Bashō. Twayne Publishers, I970). 
The following passage from Kokumin no uta, published in the November 1997 issue of Gunzō, provides further evidence of how, in the textual space of Ribi's work, untranslatability and fragmented writing influence each other, creating the kind of highly complex sentences Makino Seiichi (2013) characterizes as "extreme syntax" (kyūkyoku no shintakkusu). The story follows the American protagonist, once again based in Tōkyō, visiting his mother and mentally disabled younger brother in Washington for Christmas. Although intimate family relationships connect him to this city, the journey appears to be as an emotionally painful one due to his frustrating communication with his mother and brother.

The passage in question appears early on in the novel and describes the protagonist on an underground train to the suburbs being suddenly overcome by a feeling of unease as he realizes that, despite being surrounded by his compatriots, he is unable to explain his feelings in anything other than Japanese, not even in his mother tongue, English. The scene is described as follows:

He had no inkling that he would become involved in a crime. He was just puzzled to find himself stuck on a train rushing towards a destination he didn't want to visit, surrounded by about one hundred foreigners, none of whom, as he realized uneasily, would understand the language in which he could explain this feeling, and so he nervously sat down near the door of the smooth-running train next to a foreigner sporting a red beard-perhaps a civil servant or soldier-who seemed to weigh over 80 kilos and who held a bag filled with things for Christmas on his huge knees. (Ribi, I998, pp. I I-I 2. My translation. $)^{27}$

The second sentence includes several different narrative featuresscenic description, the main character's mental and psychological analysis, his movements-, each of which could have constituted a short separate sentence. This lengthy sentence describes the main character's act of sitting down, yet the description is extremely drawn out and features multilayered dependent clauses that detail the protagonist's thoughts and feelings. Consequently, the act of sitting down, which in reality might span a very short amount of time, is depicted as an extremely long event, or to be more

${ }_{27}$ See Appendices for the original Japanese text. 
precise, as being hidden under multilayered dependent clauses in which readers might get lost. If the protagonist's state of mind and act of "sitting down" had been described separately, using different sentences, readers might have interpreted these events and situations as happening at different moments or as being seen at different levels, thereby potentially establishing a causal or chronological relationship between them. However, these different features are put together in one single sentence, creating a striking contrast as if to illustrate that the protagonist's movement of "sitting down" happened while resisting his feeling of unease at the "language trouble." Ribi chose to construct a single sentence, albeit an extremely long and complex one, inserting frequent punctuation marks between the multilayered dependent clauses, despite this decision potentially rendering the act of reading quite difficult and slow. Nevertheless, this segmented and highly complex sentence, challenging the limits of "readability," allows the author to "translate" the protagonist's feelings of unease and awareness of the asymmetry and "untranslatability" of languages.

Thus, the striking feature of these four examples discussed here is that they are divided between a strong appetite for developing a distinctive writing style and an awareness of the "untranslatability" of languages, which interrupts the ordinary writing and reading process. However, this contradiction seems to be just on the surface. In Ribi's works, various feelings-unease, suspicious, solitude or alienation-provoked by "language trouble" in traveling situations not only constitute narrative contents, but also structure the author's narrative strategy, or even his written language in Japanese.

\section{Conclusion}

Ribi's novels are often read as a kind of resistance to the so-called "monoethnic ideology" (tan'itsu minzoku shugi), according to which Japanese literature should be written by Japanese authors, in the Japanese language, for Japanese readers. Indeed, Ribi has consistently opposed the national(istic) identity of Japanese literature in his essays and interviews, arguing that writing in Japanese, a language that is not his mother tongue, is a legitimate 
claim to what he calls "ownership of the Japanese language" (Nibongo no shoyuken). ${ }^{28}$ By this striking expression, Ribi denounces that for non-native writers in Japanese, this language is still only borrowed and their works can stand on their own if only eccentrically presented as being "written by non-native writer in Japanese" (nihongo o bogo to shinai sakka ni yotte kakareta) in parentheses. The fact that the national border is still working in Japanese literature can be evidenced by a glance at the list of the winners of the Akutagawa Prize, the most important literary prize in Japan, which has been awarded to non-native writers just solely for once in $2008 .{ }^{29}$

It is true that this criticism of the "monoethnic ideology" could be seen as paralleling a vision of our world today as being (and becoming increasingly) globalized. However, as I have attempted to show in my examples, Ribi's writing contains many aspects that do not fit this perception. On the contrary, the traveling situations described by Ribi in his novels are firmly connected to his own personal history and identity. Each of them acknowledges the unbridgeable gap between languages, especially between Japanese and English or Chinese. Rỉbi provides a revealing insight into this "untranslatability" by giving it a concrete-albeit complex-written form, creating structural coherence between his narrative and his writing style, even at the risk of challenging the limits of Japanese language within which he writes.

Thinking objectively, situations frequently occur when travelling in which we cannot go from our mother tongue to another language without some loss of meaning. Yet what makes Ribi's novels so striking and unique is the skepticism they convey on the transparency of language. When attempting to picture our world today as globalized and globalizing, we sometimes tend to have a one-sided and optimistic view, according to which the interaction with others' languages becomes more and more transparent.

${ }_{28}$ See Ribi (200I).

29 So far, Yang Yi, a Chinese-born novelist writing in Japanese, is the only non-native writer who won the Akutagawa Prize (2008), which had been established in 1935 by Kikuchi Kan (1888-1948) in honor of Akutagawa Ryūnosuke (I892-I927), one of the most important novelists of modern Japan. 
However, Ribi's texts exploring the borders between languages, in particular his written language featuring fragmented or highly multilayered sentences eruditely lead us to enhance critical awareness about this illusionary idea. As a result, they show that what I have described as "language trouble" is intricately linked to the art of writing literature as an act of language. For Ribi, whether or not the exchange between languages can be free-flowing seems to be secondary preoccupation. But rather, the focus is on if and how it becomes possible to go through the ambiguity of our world today, which is visible in his personal history, toward creating literary works in others' languages. At least, his texts and writing style seem to suggest this reading framework. In this sense, I would argue that it is difficult to read Ribi's literary works and the traveling situations they describe as merely a representation or testimony of our globalized world. The act of crossing from English into Japanese, creating a distance with one's own language, could instead be understood as a strategy for going beyond the modern globalized world order, which a number of studies mention as a file path to Ribi's border-crossing literature.

In the spring of 20I6, Rỉbi published Mohankyō, a collection of short stories and essays in which he describes for the first time his trip to Taiwan. One of the texts, an essay on Pearl Buck entitled Göingu neitibu (Going Native) finishes with the following words:

If "Going Native" truly exists, it means seeking our new life in the words created by original native speakers.

This is neither a matter of race nor of personal history but rather an issue of writing style. (Ribi, 20ı6a, p. I 8 . My translation.)

Like Mohankyō I mentioned above, this latest book is written entirely in the first person and sees the narrator-protagonist, named "Ribi," mention his other novels. In this sense, the quoted passage can be read as a metanarrative comment on the author's works. Read in this way, traveling or crossing borders in Ribi Hideo's novels could be understood as a writing style laboratory and thus a way of surviving our globalized and globalizing world. This would explain Ribi's need to write in Japanese, a language that is not his own, thereby escaping English, his mother tongue, one of the forces dramatically driving globalization. 


\section{References}

\section{Main texts}

Rïbi Hideo (I992 [20II]) Seijōki no kikoenai heya [A Room Where the Star-Spangled Banner Cannot Be Heard], including Nobenbā [The End of November] and Nakama [One of the Guys], Tōkyō: Kōdansha. Trans. Christopher D. Scott, New York: Columbia University Press.

- (I996) Ten'anmon [Tiananmen], including Pekin ekkyō-ki [Crossing the Border to Beijing], Tōkyō: Kōdansha.

-(I998) Kokumin no uta [Ode to the Nation], including Manshü ekusupuresu [Manchurian Express], Tōkyō: Kōdansha.

(2002) Henrì Takeshi Rewitsukī no natsu no kikō [Henry Takeshi Levitzky's Summer Journey], including Ka to hae no dan$s u$ [The Dance of Mosquito and Fly], Tōkyō: Kōdansha.

- (2005) Chiji ni kudakete [Thousands and Thousands of Pieces], including Konechikatto abenyu [Connecticut Avenue], Tōkyō: Kōdansha.

- (2008a) Kari no mizu [Fake Water], including Kōsokukōro nite [On a National Highway], Rōkokudō [An Old National Road] and Gaze [I Am], Tōkyō: Kōdansha.

- (2016a) Mohankyō [Model Village], including Senkyōshi gakkō gojyūnen-shi [Fifty Years Annals of the Mission School], Gōingu Neitibu [Going Native], Mihosō no mama [Still Dirt], Tōkyō: Shūeisha.

\section{Other references}

Aoki, T. (200I). Ibunka rikai [Understanding different cultures], Tōkyō: Iwanami shinsho.

- (20I0). Sakka wa idō suru [The Writers Move], Tōkyō: Shinshokan.

Damrosch, D. (2003). What Is World Literature? Princeton and Oxford: Princeton University Press.

Kaku, N. (ed.). (2013). Bairingaruna Nihongo bungaku [Japanese Literature of a Bilingual Nature], Tōkyō: Sangensha. 
Kawamura, M. (I999). Umaretara soko ga furusato: zainichi Chōsenjin bungakuron [Birth Land Is Native Land: On Japanese Literature of Korean Residents in Japan], Tōkyō: Heibonsha.

Kleeman, F.Y. (2003). Under an Imperial Sun: Japanese Colonial Literature of Taiwan and the South, Hawaii: University of Hawaii Press.

- (20I3). "Rībi Hideo no bungaku. Kan-gengoteki kūkan no kanōsei [Literature of Rỉbi Hideo. The Possibility of Literary Space between languages]," in Kaku, N. (ed.) Bairingaruna Nihongo bungaku [Japanese Literature of a Bilingual Nature], Tōkyō: Sangensha, pp. 74-93.

Komori, Y. (I998). Yuragi no Nihon bungaku [Waving Japanese literature], Tōkyō: NHK Books.

Makino, S (2013). "Nihongo no ika to tayōka. Rỉbi Hideo no kēsu sutadhi [Defamiliarizing and diversifying Japanese language. A Case Study of Rỉbi Hideo]," in Kaku, N. (ed.) Bairingaruna Nihongo bungaku [Japanese Literature of a Bilingual Nature], Tōkyō: Sangensha, pp. 47-73.

Nagaoka, M. (2009). "Gengo ni tsuite no shōsetsu. Rỉbi Hideo ron [Novel about language: study of Rỉbi Hideo]," Gunzō, 64 (6), pp. 80-IOI.

Numano, M. (I998). "Sekai no naka no nihon bungaku — arata na aidenthithī o motomete [Japanese literature in the world or the search for a new identity]," Asuteion, 49 (7), pp. I76-190.

- (2008). "Kaisetsu. Futatsu no gengo, futatsu no 'jigoku' no aida de [Comment. Between two languages, two 'hells']," in Rỉbi Hideo, Chiji ni kudakete, Tōkyō: Kōdansha bunko, pp. 268-276.

Ríbi, H. (200I). "Nihongo no 'shoyūken' o megutte [About the 'ownership' of the Japanese language],' in Nihongo o kaku heya [A Room Where I Write Japanese], Tōkyō: Iwanami shoten, pp. 46-49.

- (2007). Ekkyō no koe [Voices of Border-crossing], Tōkyō: Iwanami shoten. (2008b). En'an. Kakumei seichi e no tabi [Yan'an. A Journey to the Holy Place of Revolution], Tōkyō: Iwanami shoten. 
- (2010). Wareteki Nihongo. The World in Japanese [My Japanese language. The World in Japanese], Tōkyō: Chikuma shobō.

- (20II). "Nenpu [Chronology]," in Ten'anmon [Tiananmen], Tōkyō: Kōdansha ungee bunko, pp. 3 I 2-327.

- (20I6b). “(Taidan) Mohankyō o yomu [(Talk with On Yūjū) Read Model Village (Mohankyō)]," Sekai 887, pp. 222-234.

Sakamoto, R. (2006). “Writing as out/insiders. Contemporary Japan's $e k k y \bar{o}$ literature in globalization," in Allen, M. and Sakamoto, R. (eds) Popular Culture, Globalization and Japan, London: Routledge, pp. I37-I 57.

Sasanuma, T. (20I I). "Rỉbi Hideo ni okeru 'Taiwan' [Rỉbi Hideo in Taiwan],” Bungaku kenkyū ronshū, 29, pp. I-I4.

Tarumi, C. (I995). Taiwan no nihongo bungaku: Nihon tōchi jidai no sakkatachi [Taiwanese Literature in Japanese: Writers under the Japanese Rule], Tōkyō: Goryū shoin.

Tawada, Y. (2003). Ekusofonì: bogo no soto e deru tabi [Exophony: Traveling Out of One's Mother Tongue], Tōkyō: Iwanami shoten.

Tsuchiya, M. (ed.) (2009). Ekkyō suru bungaku [Literatures Crossing Borders], Tōkyō: Suiseisha.

Yoshihara, M. (2000), "Home Is Where the Tongue Is: Ribi Hideo to Mizumura Minae no ekkyō to gengo [Home Is Where the Tongue Is: Border-crossing and Language of Rỉbi Hideo and Mizumura Minae]," Amerika kenkyū, 34, pp. 87-I04.

\section{Appendices}

I. The original Japanese text of the quote from Seijoki no kikoenai heya:

はじめて一望のうちに見渡せる日本の夜の都会を、ベンは食 い入るように眺めつづけた。昼間と違って家とビルの輪廓は霞 み、いたるところでネオンの仮名と漢字が静かに蚌いていた。 よその少年に解るはずのない都会の秘密を、駅から駅へと伝え ていた。「ウイスキー」と「製薬」、「トルコ」と「医院」、 
それぞれ適切な色をもって、かわるがわる映ってくる都会の夢 と病の文字。

ベンはその多くの文字を知らなかった。そして、たとえ知 ることができても、けっしてその意味を解くことはできなか った。ベンはまだ、標識をほとんど読めない旅人だった。実 際に、横浜駅からすこしずつ乗りこんできた他の乗客たちの眼 には、そのことを憐れんだり、嘲ったり、ときにはベンの読み たいという強烈な青灰色の眼に気づいて驚いている表情もあつ た。(The emphasis is the author's)

\section{The original Japanese text of the quote from Ten'anmon:}

「君は大陸の人ですか」

と大陸の言語で聞こうと思ったが、「你是（ニーシル）」が 口を出る寸前に勇気がなくなり、黒い柳の葉叢が風の向きによ って突然摇れてしまったように、彼女は通路の斜め後ろの方 動き、かれの視野からいなくなった。

「你是（ニーシル）」という音がかれの口を出ようとしたの は、三十年ぶりだった。

你是於大陸出生的嗎（ニーシルユーダールーチューシエ ングデマー)?

你是在大陸長大的嗎（ニーシルヅアイダールーチヤング ダイデマー)

君は大陸で生まれたのか? 君は大陸で育ったのか? 敗 軍の島の地方都市で、三十年前のかれの耳を満たした、大陸を 失った将軍たちの大陸の言葉が、切れ切れに驶った。

「我是（ウオシル）…

とかれは逆のことを告げようと、頭の中で大陸の言葉を綴 ってみた。

「我是（ウオシル）日本…」

その後に続くはずの「人 (レン)」が、すなおに出てこなか つた。

「我是日本的（ウオシルルーベンデ）‥」と頭の中で言い 直してみた。

「我是日本的（ウオシルルーベンデ）‥」、なんだろう か、なんと言えばいいのだろうか。断片的に建った言葉が、断 片のまま宙ぶらりんとなって、やがては消えた。(The phonetic guide on the Chinese words is in the original text.) 


\section{The original Japanese text of the quote from Chiji ni kudakete:}

エア・カナダ機がスピードを落とした。滑走路の上を動い た。そして、最後の一息が切れて残りの数十メートルをあきら めたかのように、とつぜん、だがとても自然に、途中で止まっ た。

空の外でゆっくりと流れていた敷地と、その向こうに連な る森林も、その動きが止まり、白い大空の下でじっとたたずん でいた。

まわりから、英語と日本語と、すこしだけの北京語の静か な声が耳に入った。それらのざわめきの上で、スピーカーから は、五十代の男の声が聞こえた。

\section{Sometimes}

機長の声だった。機長の声は、米語のようだが、米国人の 米語よりやわらかに聞こえた。

機内に流れる機長のアナウンスの中で、Sometimesというこ とばをエドワードはこれまで聞いたことはなかった。

ときには、とエドワードは思わず日本語でささやいた。

\section{Sometimes a captain...}

ときには、機長というものは...

機長の声は、ためらつているようで、わずかに途切れた。 それから、ゆっくりとmustと言って、つづいた。

...悪いニュースを伝えなければなりません

機長は、そんなことを言っていた。

連絡が入りました

スピーカーカら流れるその声は、もう一度、一瞬だけ途切 れた。たぶん、機長室にはその連絡がすでに何時間も前に入っ たのだろう、平板な声で、

\section{the United States}

と機長がまた言いだした。

それから、ゆっくりと、優しげな口調となって、

has been a victim

と言いつづけた。 
耳に入ったそのことばは、意味をなさなかった。頭の中で 奇妙な日本語が響こうとした。

アメリカ合衆国は、被害者となった

\section{of a major terrorist attack}

アメリカ合衆国は、甚大なテロ攻撃の被害者となった

くわしいことは、今伝えられません

機内での英語の声がすこしずつ静まった。いくつかの日本 語の声と、一かたまり二かたまりの北京語の声が無邪気につづ いていた。何語ともつかないおどろきの音も何列か前と何列か 後で起った。

4. The original Japanese text of the quote from Kokumin no uta:

犯罪に遭うという可能性を、かれはすこしも意識していなか った。かれはただ、百人近くの外人の中に閉じこめられて、行 きたくないところへ、疾走する車輌に運ばれている、しかもそ んなためらいの気持ちを表現できる言語は、まわりの誰にも通 じないという不安にとらわれながら、清潔でなめらかな動きで 走る車輛のドアの近くの二人席に、体重が八十キロもあるだろ う赤ひげの、役人だろうか軍人だろうか、クリスマスの買物を あふれんばかりにつめたショッピング・バッグを巨大な膝の上 に乗せた外人のとなりにこわごわと腰掛けたのである。（The emphasis is the author's.) 